\title{
Volatile Anesthetic Sevoflurane Precursor 1,1,1,3,3,3-Hexafluoro-2-Propanol (HFIP) Exerts an Anti-Prion Activity in Prion-Infected Culture Cells
}

\author{
Takuto Shimizu ${ }^{1,5} \cdot$ Emiko Nogami $^{2} \cdot$ Yuka Ito $^{3,4} \cdot$ Kazuo Morikawa $^{5} \cdot$ Masaki Nagane $^{1} \cdot$ Tadashi Yamashita $^{1}$. \\ Tsuyoshi Ogawa $^{6} \cdot$ Fuyuki Kametani $^{7} \cdot$ Hisashi Yagi ${ }^{3,4} \cdot$ Naomi Hachiya $^{5}$ (i)
}

Received: 17 November 2020 / Revised: 20 April 2021 / Accepted: 12 May 2021 / Published online: 27 May 2021

(c) The Author(s) 2021

\begin{abstract}
Prion disease is a neurodegenerative disorder with progressive neurologic symptoms and accelerated cognitive decline. The causative protein of prion disease is the prion protein $(\operatorname{PrP})$, and structural transition of PrP from the normal helix rich form $\left(\operatorname{PrP}^{\mathrm{C}}\right)$ to the abnormal $\beta$-sheet rich form $\left(\mathrm{PrP}^{\mathrm{Sc}}\right)$ occurs in prion disease. While so far numerous therapeutic agents for prion diseases have been developed, none of them are still useful. A fluorinated alcohol, hexafluoro isopropanol (HFIP), is a precursor to the inhalational anesthetic sevoflurane and its metabolites. HFIP is also known as a robust $\alpha$-helix inducer and is widely used as a solvent for highly aggregated peptides. Here we show that the $\alpha$-helix-inducing activity of HFIP caused the conformational transformation of the fibrous structure of PrP into amorphous aggregates in vitro. HFIP added to the $\mathrm{ScN} 2 \mathrm{a}$ cell medium, which continuously expresses $\mathrm{PrP}^{\mathrm{Sc}}$, reduced $\mathrm{PrP}^{\mathrm{Sc}}$ protease resistance after 24-h incubation. It was also clarified that ScN2a cells are more susceptible to HFIP than any of the cells being compared. Based on these findings, HFIP is expected to develop as a therapeutic agent for prion disease.
\end{abstract}

Keywords Prion · Prion disease $\cdot$ Prion protein · Anti-prion drug $\cdot$ Hexafluoro isopropanol $\cdot$ Amyloid $\cdot$ Amyloid-beta (A $\beta)$. Neurodegeneration $\cdot$ Neurodegenerative disease

Naomi Hachiya

naomi.hachiya@cgco.co.jp; naomihachiya@gmail.com

1 Laboratory of Biochemistry, School of Veterinary Medicine, Azabu University, 1-17-71 Fuchinobe, Chuo-ku, Sagamihara-shi, Kanagawa 252-5201, Japan

2 Chemical Research Center, Central Glass Co., Ltd., 17-5, Nakadai 2, Kawagoe City, Saitama 350-1159, Japan

3 Faculty of Engineering, Tottori University, 4-101 Koyama-Minami, Tottori 680-8552, Japan

4 Center for Research on Green Sustainable Chemistry, Tottori University, 4-101 Koyama-Minami, Tottori 680-8552, Japan

5 Tokyo Metropolitan Industrial Technology Research Institute, 2-4-10 Aomi, Koto-Ku, Tokyo 135-0064, Japan

6 Chemicals Business Development Department, Central Glass Co., Ltd, Kowa-Hitotsubashi Building, 7-1 Kanda-Nishikicho 3, Chiyoda-ku, Tokyo 101-0054, Japan

7 Tokyo Metropolitan Institute of Medical Science, 2-1-6 Kamikitazawa, Setagaya-Ku, Tokyo 156-8506, Japan

\section{Introduction}

Prions are infectious pathogens that cause fatal neurodegenerative diseases by altering the three-dimensional structure of the causative protein by yet unknown mechanism. The protein that causes prion disease is the prion protein (PrP); PrP undergoes structural conversion from a normal form of $\alpha$-helix-rich $\operatorname{PrP}^{\mathrm{C}}$ to an abnormal form $\beta$-sheet-rich $\operatorname{PrP}^{\mathrm{Sc}}$ although there is no difference of amino acid sequence between them [1]. There are three types of human prion disease: idiopathic/sporadic, hereditary, and infectious. The most common type is idiopathic/sporadic, accounting for around $80 \%$ of all prion diseases [2]. Approximately $15 \%$ are inherited with several mutations in the open reading frame of the PrP gene, and mutations in hereditary prion disease raise the risk of a structural change in PrP [3]. Structural changes in PrP due to extrinsic $\operatorname{PrP}^{\mathrm{Sc}}$ occur in infectious prion disease, including variant CJD (vCJD) [4]. vCJD, thought to be caused by eating prion-affected beef, occur in relatively young patients and are characterized by the presence of florid plaques, 
especially in the cerebral and cerebellar cortices. Interestingly, the NMR study also revealed that the conformation of PrP in bovine and humans is essentially the same [5]. Methionine homozygosity (MM) at codon 129 of the prion protein encoding gene PRNP has been observed in VCJD patients. In addition, vCJD in $129 \mathrm{MV}$ and $129 \mathrm{VV}$ patients has a long incubation period and is a concern for secondary infection [6].

PrP is a protein belonging to the secretory pathway with an endoplasmic reticulum translocation signal at the amino terminus and a glycosylphosphatidylinositol (GPI) additional signal at the carboxyl terminus for lipid raft targeting [7]. We have previously reported that endogenous PrP is localized in the cell membrane and microtubules and moves intracellularly $[8,9]$. PrP is also present in mitochondria [10-12] and we have recently discovered that the 18 amino acids in the residues $122-139$ of PrP are a cryptic mitochondrial targeting signal of PrP [13]. Despite the many attempts to elucidate the physiological role of $\operatorname{PrP}$, it is still not well understood $[14,15]$.

Sevoflurane is a commonly used inhalation anesthetic with relatively fewer side effects than other inhalation anesthetics because it is not metabolized to acyl halides $[16,17]$. The fluorinated alcohol 1,1,1,1,3,3,3-hexafluoro2-propanol (HFIP) is a precursor of sevoflurane. Metabolized HFIP is excreted in the urine as HFIP-glucuronide after phase I oxidation reaction by cytochrome P-450 2E1 (CYP2E1) and phase II glucuronidation reaction by UDPglucuronosyltransferase $[18,19]$.

No toxicity for HFIP at clinically derived concentrations has been reported to date. Besides, HFIP suppresses endotoxin-stimulated inflammatory mediator secretion and improves the survival rate of septic peritonitis mice models [20]. Fluorinated alcohols, such as HFIP, have a particularly strong protein-denaturing activity and break the $\beta$-sheet structure leading to $\alpha$-helix. Therefore, it has been used as a solvent to dissolve peptide aggregates such as amyloid $\beta(\mathrm{A} \beta)$ peptides [21-24].

$\operatorname{PrP}^{\mathrm{Sc}}$ is thought to consist of many structures rather than of a uniform structure. As a therapeutic agent for prion diseases, attempts have also been made to identify compounds that inhibit the structural conversion of $\operatorname{PrP}^{\mathrm{C}}$ to $\mathrm{PrP}^{\mathrm{Sc}}$, however many of these drugs have resulted in drug resistant prion strains [25]. On the other hand, HFIP has strong $\alpha$-helix-inducing activity, should be able to unwind $\mathrm{PrP}^{\mathrm{Sc}}$ into $\mathrm{PrP}^{\mathrm{C}}$, and $\mathrm{PrP}^{\mathrm{Sc}}$ structure itself will be normalized. If this is the case, issues about the development of $\mathrm{PrP}^{\mathrm{Sc}}$ drug resistant strains can be eliminated.

In this study, we explored the possibility of HFIP as a therapeutic drug for prion diseases using recombinant PrP and scrapie-infected mouse neuroblastoma cells, an established in vitro model of prion disease.

\section{Results}

The effect of HFIP to PrP fibrils produced by the recombinant PrP was observed using transmission electron microscopy (TEM). When recombinant PrP was incubated with PBS in the absence of HFIP for $24 \mathrm{~h}$, PrP fibrillated and formed an unbranched linear structure (Fig. 1A (a)-(c), magnified images (d)-(f)). When the PrP fibrils were incubated with $10 \mathrm{mM}$ HFIP for $24 \mathrm{~h}$ at $37^{\circ} \mathrm{C}$, the linear PrP fibrils changed into three-pronged structures (Fig. 1A (g)-(i), magnified images (j)-(1), Arrowheads). Moreover, $20 \mathrm{mM}$ of HFIP completely transformed the fibrous PrP into an amorphous shape (Fig. $1 \mathrm{~A}(\mathrm{~m})-(\mathrm{o})$, magnified images (p)-(r)), indicating that HFIP induces a drastic conformation-changing activity to fibrous PrP. Compared to PrP, the A $\beta$ (1-40) (Fig. 1B (a)-(f)) did not alter the fibrous structure in the presence of HFIP (Fig. 1B (g)-(r)), but a rather enhanced association of the amyloid fibrils. In addition, $\mathrm{CD}$ spectroscopy was used to measure changes in the secondary structure of PrP and A $\beta(1-40)$ after HFIP treatment. Since CD spectroscopy makes it difficult to evaluate at lower HFIP concentrations than in other experimental conditions, we used higher concentrations of HFIP and substrates. The $\beta$-sheet structure of PrP has modified to $\alpha$-helix-rich HFIP-dependent structure (Fig. 1C (a)) while the $A \beta(1-40)$ structure has remained unchanged up to $2.45 \mathrm{M}$ HFIP (Fig. 1C (b)). These findings indicate that HFIP has a distinct effect on $\operatorname{PrP}$ and $A \beta(1-40)$.

$\mathrm{PrP}^{\mathrm{C}}$ is easily digested by the proteolytic enzyme proteinase $\mathrm{K}(\mathrm{PK})$, while $\mathrm{PrP}^{\mathrm{Sc}}$ exhibits partial PK resistance. $\mathrm{PrP}^{\mathrm{Sc}}$ formation inhibition is a major target for therapeutic intervention in prion disease; thus, ScN2a cells continuously producing $\operatorname{PrP}^{\mathrm{Sc}}$ are valuable models for detecting anti-prion activity [26]. PK resistance of $\mathrm{PrP}^{\mathrm{Sc}}$ did not change with the incubation at 5 or $10 \mathrm{mM}$ of HFIP for $24 \mathrm{~h}$; however, HFIP at $15 \mathrm{mM}$ decreased PK resistance of $\mathrm{PrP}^{\mathrm{Sc}}$ by approximately $40 \%$ compared to the control. When the HFIP concentration increased to $20 \mathrm{mM}$, the PK resistance bands of $\operatorname{PrP}^{\mathrm{Sc}}$ significantly decreased (Fig. 2).

If a structural change in $\operatorname{PrP}^{\mathrm{Sc}}$ decreases $\mathrm{PK}$ resistance in $\mathrm{ScN} 2 \mathrm{a}$ cells, it should be recognized by various intracellular chaperones. In that case, the protein quality control system should be triggered, causing changes in the subcellular distribution of PrPs [27]. Therefore, we used indirect immunofluorescence antibody technique to investigate the localization change of endogenous PrP in the presence of HFIP (Fig. 3A).

Endogenous PrP is localized on microtubules. As with other cargo proteins, PrP does not bind directly to microtubules but binds to motor and adaptor proteins for anterograde and retrograde transport $[8,9]$. At this time, the angle at which a cargo molecule, such as PrP, binds to 


\section{A}

$0 \mathrm{mM}(\mathrm{a})$
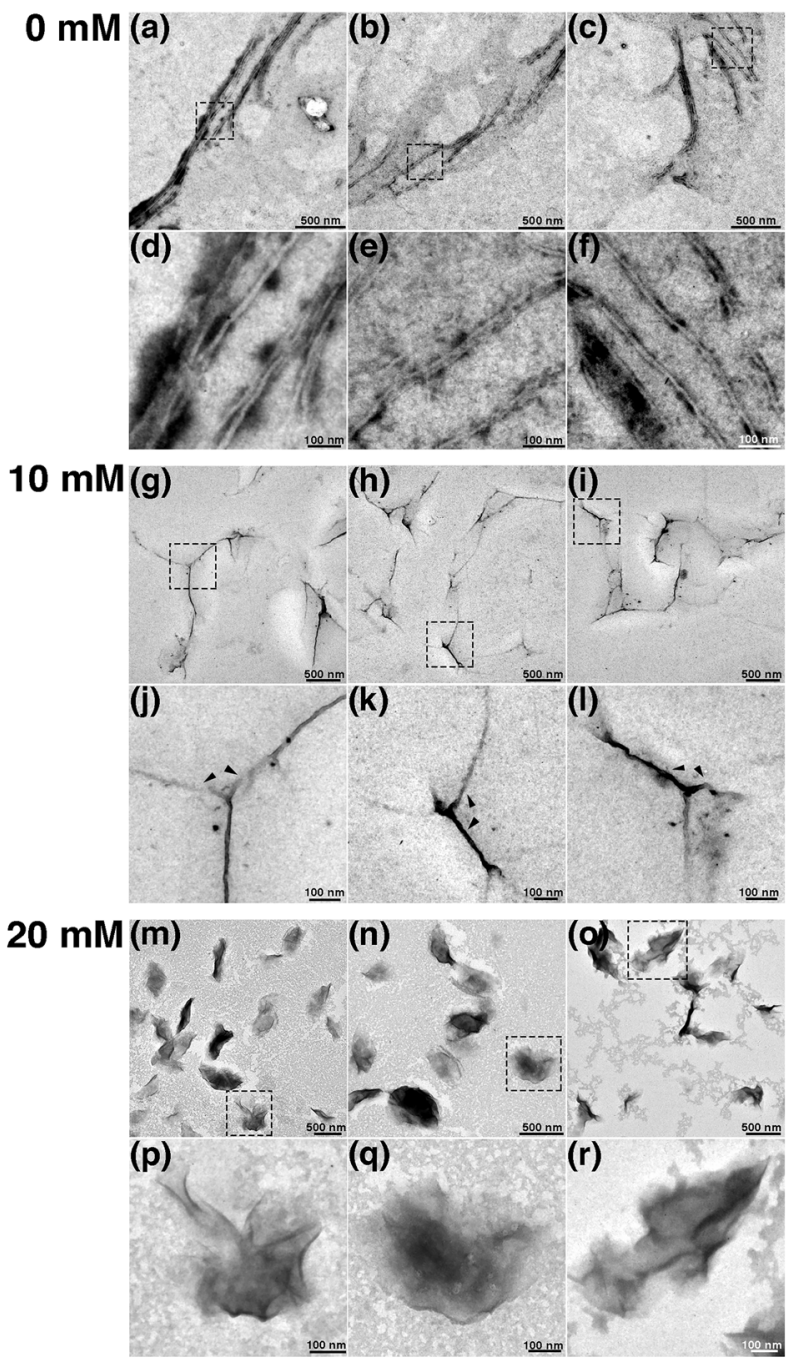

C

(a)

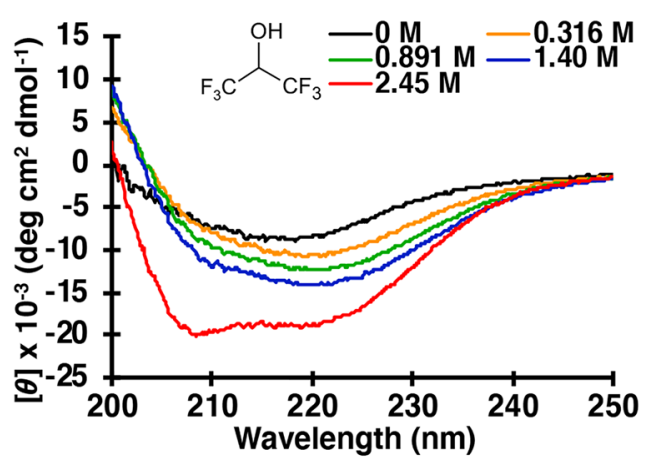

B
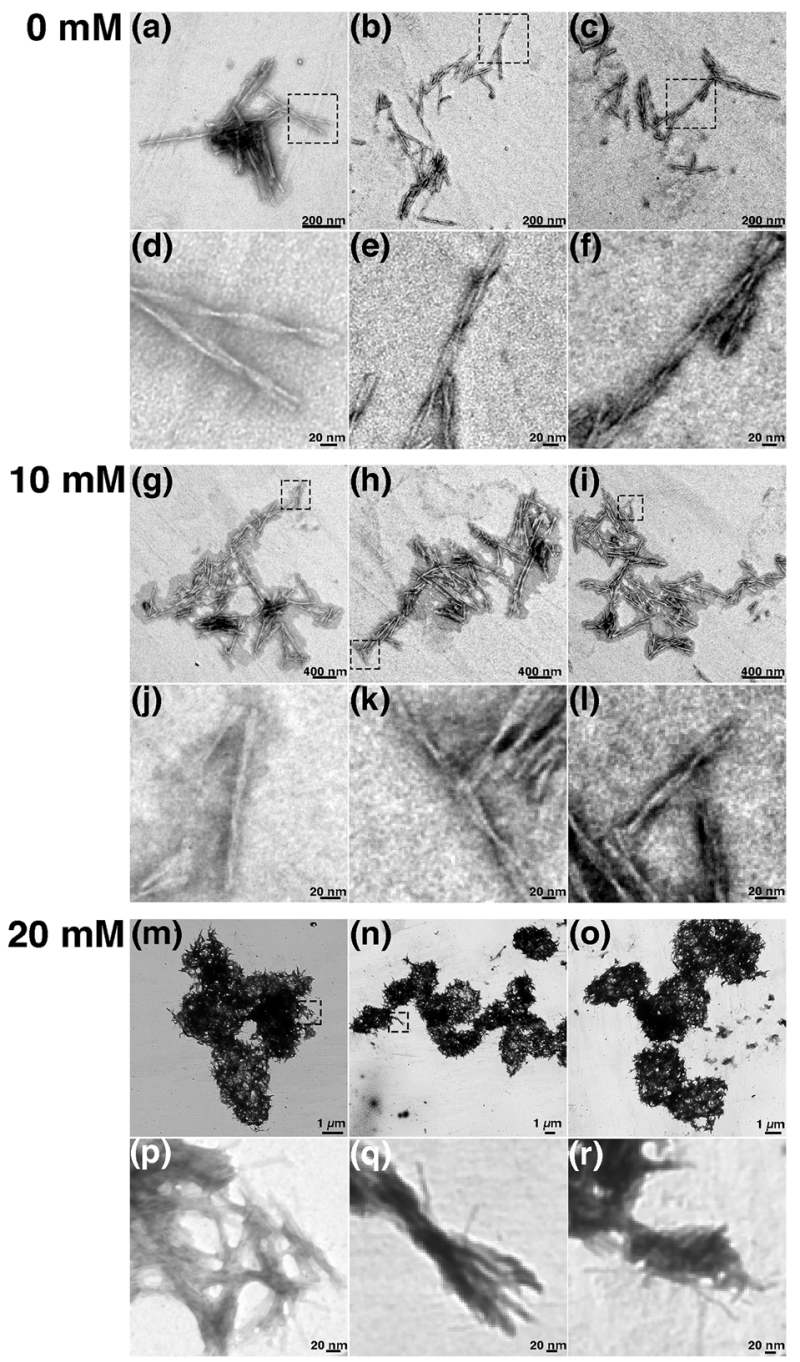

(b)

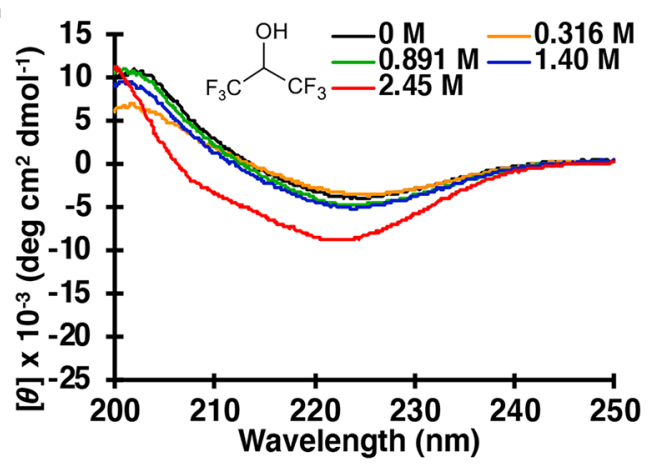

Fig. 1 HFIP has a different effect on $\operatorname{PrP}$ and A $\beta$ (1-40). A Ultrastructure of PrP fibers. When recombinant PrP was incubated with PBS in the absence of HFIP for $24 \mathrm{~h}$, PrP fibrillated and formed an unbranched linear structure (A $(a)-(c)$, magnified images $(d)-(f)$ ). After the incubation with $10 \mathrm{mM}$ HFIP for $24 \mathrm{~h}$ at $37^{\circ} \mathrm{C}$, the $\operatorname{PrP}$ fibrils were transformed into three-pronged structures. (A $(g)-(i)$, magnified images $(j)-(l)$, Arrowheads). Only amorphous aggregates have been found in $20 \mathrm{mM}$ of HFIP (A $(m)-(o)$, magnified images $(p)-(r))$. The scale bar for each panel is shown in the figure. B Ultrastructure of the amyloid fibrils of $A \beta(1-40)$. The fibrous structure of $\mathrm{A} \beta(1-40)$ did not alter with the 24-h incubation of 10 and $20 \mathrm{mM}$ of HFIP. Instead, amyloid fibrils have been associated in a concentration-dependent manner with HFIP. C CD measurement of PrP and A $\beta$ (1-40) amyloid. The secondary structure of PrP modified with the HFIP concentration $(a)$. A $\beta(1-40)$ amyloid is resistant to HFIP and is unlikely to undergo secondary structural changes $(b)$ 


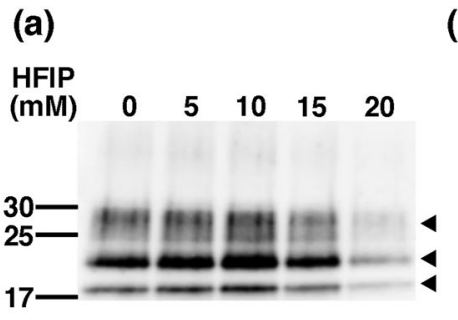

(c)

(b)

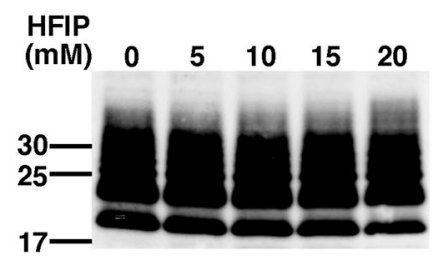

Fig. 2 HFIP increases the PK sensitivity of $\mathrm{ScN} 2 \mathrm{a}$ cells. HFIP was added to the medium of ScN2a cells as follows; 0, 5, 10, 15 and $20 \mathrm{mM}$. After culturing cells for $24 \mathrm{~h}$, PK resistance was detected as in Materials and Methods. a Western blotting of PK-resistant bands (The unglycosylated, mono and diglycosylated PrP forms. Arrowheads.) of PrP. The amount of protein used in this assay was $100 \mu \mathrm{g} /$ tube. b Quantitative result. The statistically significant difference was shown by $* p<0.05$, $* *<0.01$ for $0 \mathrm{mM}$ HFIP. c Samples without PK treatment were subjected to SDS-PAGE and Western blotting with an anti-PrP antibody

microtubules through an adaptor molecule is not always constant and can take on a 360-degree configuration from microtubules. As a result, some PrPs on microtubules merge yellow while others do not, such as when PrPs are 90-degrees away from the microtubules. Even under such circumstances, PrPs in Fig. 3A were sufficiently close to the microtubules, and some yellowish merged foci were found in the magnified images, so we concluded that HFIP had no effect on PrP subcellular localization or association with microtubules (ScN2a; Fig. 3A(a), Fig. 3B(a), N2a; Fig. 3B(b)).

Maintaining the membrane potential of mitochondria ensures that normal energy production is being performed and indicates that cells exhibit a healthy state. JC-1 dye accumulates at the mitochondrial membrane in a potential-dependent manner: when the membrane potential is maintained, aggregated JC-1 fluoresces red, but when the membrane potential decreases, JC-1 remains monomeric and emits green fluorescence. Since HFIP did not affect the membrane potential of mitochondria in both cells $(\mathrm{ScN} 2 \mathrm{a}$; Fig. 3A (a) (JC-1), N2a; Fig. 3A (b) (JC-1)), the intracellular effect of the addition of HFIP was, if any, extremely minimal.

Finally, the sensitivity of the cultured cells to HFIP was examined by crystal violet staining. As shown in Fig. 4(a), in N2a cells, HFIP did not affect the cell viability up to a concentration of $20 \mathrm{mM}$. The susceptibility of non-neuronal cells to HFIP was also examined in the same way using COS-7 cells, which are fibroblasts, and they were resistant up to a concentration of $20 \mathrm{mM}$, similar to $\mathrm{N} 2$ a cells (Fig. 4(b)). On the other hand, the viability of ScN2a cells was reduced by about $30 \%$ compared to N2a cells at a HFIP concentration of $15 \mathrm{mM}$. At a HFIP concentration of $40 \mathrm{mM}$, most of the $\mathrm{ScN} 2 \mathrm{a}$ cells failed to survive, while N2a cells could grow by about $40 \%$. Therefore, it was suggested that $\mathrm{ScN} 2 \mathrm{a}$ cells were more susceptible to HFIP.

\section{Discussions}

Persistent prion infected $\mathrm{ScN} 2$ a cells have been commonly used as a pre-screening step to discover new anti-prion agents. To date, an assay system using $\mathrm{ScN} 2$ a cells has been used to classify anti-prion agents such as antibodies [28], dominant-negative molecules [29, 30] and low molecular weight compounds [31]. However, despite so many attempts, no successful cure and clinically beneficial drugs for prion disease have been found.

Fluorinated alcohols, such as HFIP, are unique alcohols in which fluorine is bound to carbon rather than hydrogen while sharing a similar overall structure with 'natural' alcohols. Since the electronegativity of the fluorine molecule is strong, it destabilizes the hydrophobic interaction of the substrate molecules and facilitates the bonding of intramolecular hydrogen. This activity is thought to help HFIP break the $\beta$-sheet structure and induce $\alpha$-helical conformation; thus, HFIP is also used as a solvent for $\mathrm{A} \beta$ peptides with a high aggregate propensity [23, 24].

In a previous study, Wille et al. reported that the treatment of prion rods made from scrapie-infected Syrian hamster brain extract with HFIP had modified their structure to flat ribbon-shaped [32]. In this regard, we have found that the incubation of PrP fibrils consisted of recombinant protein with HFIP has modified the structure into amorphous aggregates (Fig. 1A).

Notably, the helix-inducing activity of HFIP was reported only at high HFIP concentrations in previous studies. For example, when $A \beta$ (11-28) containing the core region of the $\mathrm{A} \beta$ aggregation was used as a substrate, the helix structure was seen in a mixture of the $90 \%$ HFIP and $10 \%$ water in CD measurements, while the water content increased to $90 \%$, the $\beta$-sheet content has increased [22]. Furthermore, low concentrations of HFIP have also been reported to increase the formation of $\mathrm{A} \beta$ fibril $[33,34]$.

$10 \mathrm{mM}(0.17 \%)$ or $20 \mathrm{mM}(0.34 \%)$ of HFIP were used in our experiments and thus $\mathrm{A} \beta$ (1-40) fibrils did not alter the conformation and induced the association of fibrils (Fig. 1B). The difference in the effect of HFIP on PrP and $\mathrm{A} \beta$ amyloid fibrils at these concentrations may be due to 
A

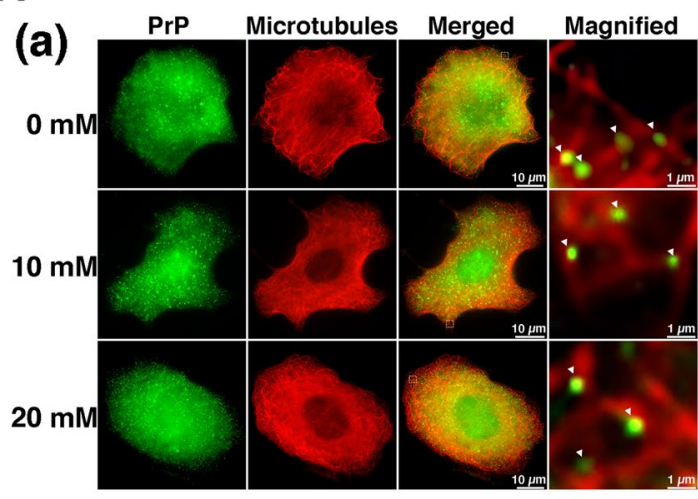

(b)

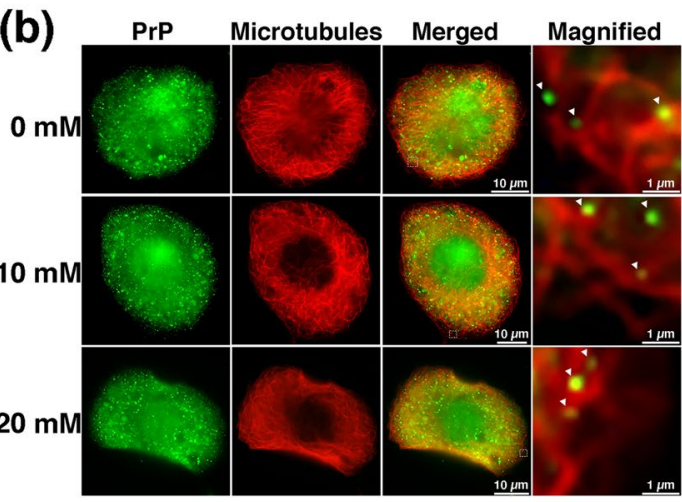
JC-1
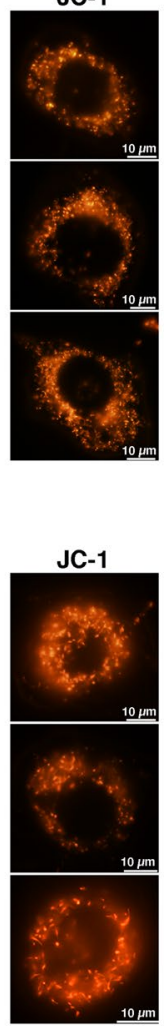

B

(a)

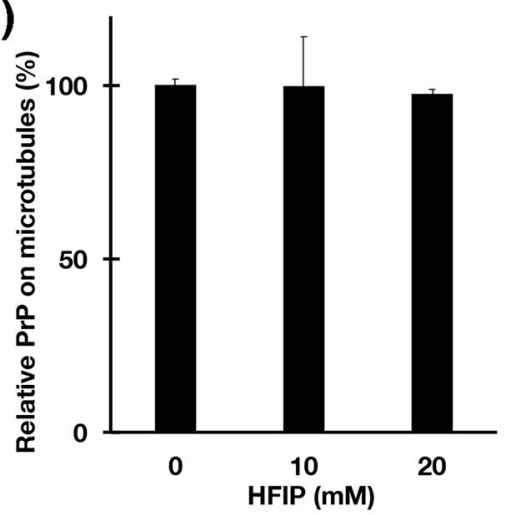

(b)

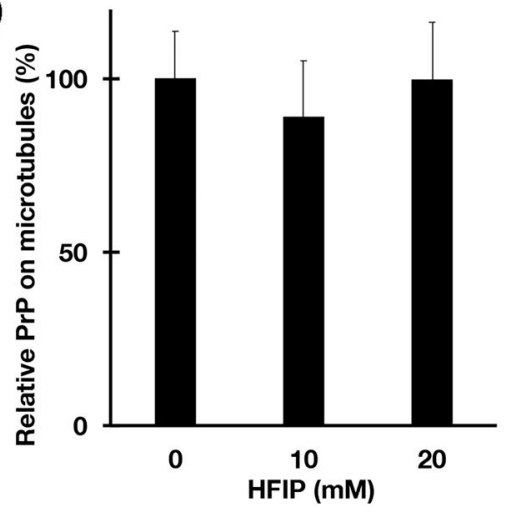

Fig. 3 Subcellular localization of endogenous PrP in the presence of HFIP and mitochondrial membrane potential. A To identify endogenous $\operatorname{PrP}$ in $\mathrm{ScN} 2 \mathrm{a}(a)$ and $\mathrm{N} 2 \mathrm{a}(b)$ cells, anti-PrP peptide antibody (PrP 76-90), which recognizes the N-terminal region of PrP, was used. An anti-tubulin antibody was used to detect microtubules. Arrowheads indicate PrP (green) on microtubules (red). JC-1 staining revealed that mitochondrial membrane potential was maintained nor-

the different construction of each fibril. A $\beta(1-40)$ fibrils form a tight cross- $\beta$ structure, with almost $90 \%$ of the molecule being the backbone $[35,36]$. Thus, HFIP is presumably unable to reach the inside of the molecule and stays on the surface of the fibrils, which is thought to promote the association of the fibers. Whereas PrP consists of a nonstructural region, a three-helical structure, and a domain structure consisting of two antiparallel $\beta$-chains [37, 38]. In addition, Wang et al. recently reported that PrP fibers with recombinant full-length human $\operatorname{PrP}^{\mathrm{C}}$ (residues 23-231) made up of two protofibrils entwined in the left-handed helix using cryo-electron microscopy [39]. As a result, PrP fibrils can easily undergo more alteration, allowing HFIP to enter the inside of the molecule and transfer the structure a fibrous to amorphous.

$\operatorname{PrP}^{\mathrm{Sc}}$ accumulates in the cell membrane, and the $\mathrm{PrP}^{\mathrm{C}}$-to-PrP ${ }^{\mathrm{Sc}}$ conversion process is thought to occur primarily in cell membrane lipid rafts or extracellularly [40]. If HFIP induces structural modification of $\mathrm{PrP}^{\mathrm{Sc}}$ within mally even in the presence of HFIP. B The number of PrPs on microtubules was counted for fluorescent immunostaining. The number of PrPs located on microtubules per unit area $(3 \mu \mathrm{m} / \mathrm{each})$ was counted. The relative percent value was set at $100 \%$ of the amount of PrPs found on microtubules in the absence of HFIP. The number of PrPs found on microtubules in the presence of HFIP has been counted and measured. The bars in the figure represent the standard error

ScN2a cells that alters the PK sensitivity (Fig. 2), intracellular molecular chaperones may have been recognized and their protein quality control system will be triggered. Consequently, the intracellular distribution of PrP will be changed [41]. However, this was not the case in our experimental findings (Fig. 3); thus, HFIP may not reached the inside of the cell, and it is more appropriate to think that the decrease in PK resistance due to the structural change of $\mathrm{PrP}^{\mathrm{Sc}}$ occurred on the cell membrane. Of note, previous screening of anti-prion activity using $\mathrm{ScN} 2$ a cells required long incubation for periods of days [42-44] to confirm the anti-prion effect. In view of this, it is remarkable that HFIP was successful in a $24 \mathrm{~h}$ treatment.

The concentration range of inhibitory HFIP activity of $\mathrm{PrP}^{\mathrm{Sc}}$ formation in $\mathrm{ScN} 2 \mathrm{a}$ cells is between 15 and $20 \mathrm{mM}$, as shown in Fig. 2. On the other hand, the cytotoxicity of HFIP increased significantly from $20 \mathrm{mM}$ onwards, as shown in Fig. 3. The therapeutic window of HFIP for $\mathrm{ScN} 2 \mathrm{a}$ cells, therefore, appears to be very small. Besides, 

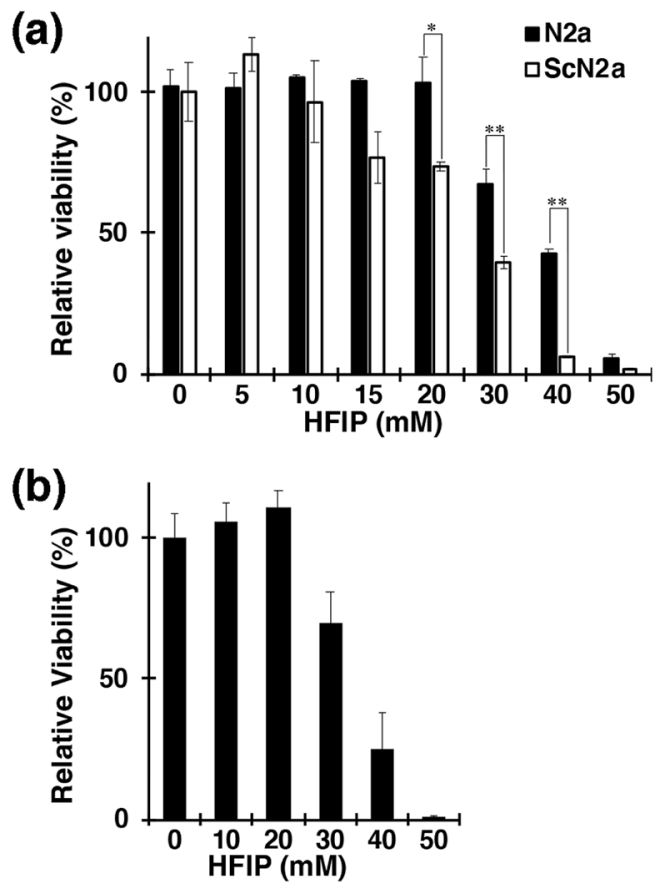

Fig. 4 Cytotoxicity of HFIP. ScN2a cells were susceptible to HFIP. After adding HFIP at the concentration shown in the figure to the medium of N2a (a), ScN2a (a) and COS-7 (b) cells, cells were cultured for $24 \mathrm{~h}$ then stained with crystal violet to count the viable cells. Bars in the graph indicate the SD. The statistically significant difference in panel (a) was shown by $* p<0.05 * * p<0.01$ for N2a cells

the $\alpha$-helix-inducing activity of HFIP is non-specific, which may cause serious side effects. Thus, it is difficult to immediately demonstrate HFIP itself as a therapeutic agent for prion disease. To solve these problems, it is important to synthesize HFIP derivatives in which the concentration that causes cytotoxicity and the concentration that causes $\alpha$-helix-inducing activity are different. Furthermore, it is also important that the HFIP derivative has substrate specificity for $\operatorname{PrP}$ and that the $\alpha$-helix-inducing activity of HFIP does not function non-specifically.

Lipid rafts are highly active, short-lived microdomains found in cholesterol- and sphingolipid-rich cell membranes. It is also involved as a platform for important cellular pathways such as membrane transport, signal transduction, and immune response activation [45]. The abundance and efficacy of these microdomains are highly dependent on the availability of cholesterol [46, 47]. Biosynthesis of cholesterol has been reported to be enhanced by prion infection [48], suggesting a link between the metabolism of cholesterol and the transmission of prion. Cholesterol is also required for PrP cell surface expression and stabilization [49], and $\operatorname{PrP}^{\mathrm{Sc}}$ with GPI anchors is present in lipid rafts [50]; thus, cholesterol depletion inhibits prion replication by inhibiting the transport of $\operatorname{PrP}$ to lipid rafts $[51,52]$.
In general, alcohol has the activity of depleting cholesterol from the target cell membrane and can increase the membrane's fluidity. Fluoride alcohols have been reported to cause lipid bilayer leaks, reduce lipid acyl chain order, alter the temperature of transition phase lipids [53], and induce micellar aggregation [54]. Low concentrations of HFIP (1-3 mM) are known to influence the ion permeability of membrane proteins such as $\mathrm{Kv} 1.3 \mathrm{~K}^{+}$channels [55] and gramicidin channels [53]. Therefore, we cannot rule out the possibility that HFIP may have destabilized lipids in our experiments and caused a reduction in $\mathrm{PK}$ tolerance in $\mathrm{PrP}^{\mathrm{Sc}}$. It will be necessary to develop HFIP derivatives that do not affect lipids or display off-target effects to address this issue.

ScN2a cells are highly susceptible to HFIP, and approximately $40 \%$ of the cells died in the presence of $20 \mathrm{mM}$ of HFIP. Whereas the same condition did not significantly kill N2a and COS-7 cells. One possible reason for the disparity in HFIP-susceptibility of $\mathrm{ScN} 2$ a cells may be that the cell membranes' lipid composition in these cells might not be the same. Consequently, there could be a difference in sensitivity to HFIP for the reasons described above.

Interestingly, the mitochondrial membrane potential in ScN2a cells, which survived $20 \mathrm{mM}$ HFIP, was normal even in the presence of $\mathrm{PrP}^{\mathrm{Sc}}$ (Fig. 3A). The localization of endogenous PrP was also normal, indicating healthy state. Considering that $\mathrm{ScN} 2 \mathrm{a}$ cells are more sensitive to HFIP than N2a cells (Fig. 4A), this result also suggests that treatment of ScN2a cells with HFIP eliminates HFIP-sensitive cell populations and allows only healthy cells. Furthermore, a small molecule such as HFIP (molecular weight 168.04) can be useful as a therapeutic agent for neurodegenerative diseases because it can easily cross the blood-brain barrier, which is typically permeable to molecules with molecular weights below 400 [56]. Therefore, the pharmacokinetics of HFIP, a small molecule compound, may be beneficial.

As shown in previous research on the development of therapeutic agents for prion disease, the experimental approach using cultured cells is a very simplified model compared to the in vivo situation. In addition to cell culture experiments, it is essential to conduct animal experiments in the future.

\section{Materials and Methods}

\section{Cell Culture}

Mouse neuroblastoma Neuro2a (N2a) and COS-7 cells were obtained from the American Type Culture Collection. ScN2a cells were kindly supplied by Dr. Horiuchi (Hokkaido University, Japan). N2a cells and ScN2a cells were grown in Eagle's Minimum Essential Medium, COS-7 cells were grown in Dulbecco's modified Eagle's medium containing 
$100 \mathrm{units} / \mathrm{ml}$ of penicillin and $100 \mu \mathrm{g} / \mathrm{ml}$ of streptomycin complemented by $10 \%$ of fetal bovine serum and $5 \%$ of $\mathrm{CO}_{2}$ in the humid incubator at $37^{\circ} \mathrm{C}$.

\section{Recombinant PrPs}

The recombinant full-length hamster $\operatorname{PrP}(23-231)$ used for TEM observation was obtained from Thermo Fisher Scientific Prionics AG (Schlieren, Switzerland) and dissolved in PBS at a concentration of $1 \mu \mathrm{g} / \mu \mathrm{l}$. Since the measurement of CD spectra requires a larger amount of PrP, E. coli was used to express mouse recombinant PrP for the measurement. Briefly, the full-length mouse PrP (23-230) expression vector encoding amino acid residues 23-230 of mouse PrP [30] was transfected into the E. coli BL21 (DE3) strain (Merck KGaA, Darmstadt, Germany) and pre-cultured in LB Broth (Invitrogen) at $37^{\circ} \mathrm{C}$ for 18 h. E. coli was further inoculated in Terrific Broth (Invitrogen) containing 0.4\% Glycerol at $37{ }^{\circ} \mathrm{C}$ for $3 \mathrm{~h}$. Isopropyl- $\beta$-D-thiogalactopyranoside was added to the induction of expression for PrP at the final concentration of $500 \mu \mathrm{M}$. PrP was accumulated in E. coli as inclusion bodies. After the solubilization of the inclusion bodies with solubilization buffer (50 mM Tris- $\mathrm{HCl}(\mathrm{pH} 7.5)$, $8 \mathrm{M}$ Urea, $150 \mathrm{mM} \mathrm{NaCl}, 500 \mu \mathrm{M}$ PMSF), the sample was centrifuged, and the resulting supernatant was applied to a Ni-Sepharose column (Cytiva, Tokyo, Japan) for the purification of PrP using the octapeptide repeat region of PrP has an affinity for nickel ions.

\section{In Vitro Fibrillogenesis of PrP and A $\beta$ (1-40)}

Hamster recombinant PrP used for TEM observation and mouse recombinant $\mathrm{PrP}$ used for $\mathrm{CD}$ spectrum measurement were dissolved in PBS and $5 \mathrm{mM}$ Tris- $\mathrm{HCl}(\mathrm{pH} 7.5)$, respectively, and allowed to form fibers by standing. A $\beta$-peptide (Human, 1-40) (HCl Form) (Peptide Institute, Osaka, Japan) was dissolved in $0.05 \%$ ammonia water (Fujifilm Wako, Osaka, Japan) to $500 \mu \mathrm{M}$. A $\beta$ (1-40) fibrils used for TEM observation were diluted by adding $50 \mathrm{mM}$ sodium phosphate (pH 7.5) to a concentration of $100 \mu \mathrm{M} .150 \mu \mathrm{l}$ of the solution was added to a $2 \mathrm{ml}$ tube (Eppendorf AG, Hamburg, Germany) and shaken at 1,500 rpm for $16 \mathrm{~h}$ at room temperature using a MicroMixer E-36 (TAITEC CORPORATION, Saitama, Japan) to form fibers. For the samples used for CD spectra, A $\beta$ (1-40) was diluted to $100 \mu \mathrm{M}$ using PBS, and then $300 \mu$ of the solution was added to a centrifuge tube. The sample was shaken at $250 \mathrm{rpm}$ for $12 \mathrm{~h}$ at $37^{\circ} \mathrm{C}$ using a BR-23FP (TAITEC CORPORATION, Saitama, Japan).

\section{Ultrastructure of PrP and $A \beta$ (1-40)}

The recombinant $\operatorname{PrP}$ and $\mathrm{A} \beta(1-40)$ were suspended at 14.6 $\mu \mathrm{M}$ then incubated with HFIP (Central Glass Co., Ltd.
Tokyo, Japan) at $37^{\circ} \mathrm{C}$ for $24 \mathrm{~h}$, followed by glutaraldehyde fixation. $3 \mu \mathrm{l}$ of specimens were added to the formvar-carbon-coated grids. The same volume of $1 \%(w / v)$ Potassium Eu-encapsulated Preyssler-type Phosphotungstate (FUJIFILM Wako Pure Chemical Co. Osaka, Japan) was applied to the grid. Specimens were observed by Titan Cubed G2 60-300 (FEI Group, Hillsboro, Oregon, USA).

\section{Circular Dichroism (CD) assay}

The mouse recombinant PrP was dialyzed in $5 \mathrm{mM}$ of Tris- $\mathrm{HCl}(\mathrm{pH} 7.5)$, treated with HFIP at room temperature for $3 \mathrm{~h}$ at the concentration shown in the figure, then $\mathrm{CD}$ measurement (J-820, JASCO Corporation, Tokyo, Japan) was performed. Before the CD measurement, $A \beta(1-40)$ was diluted in PBS, followed by shaking at $250 \mathrm{rpm}$ (TAITEC BioShaker BR-23FP), at $37{ }^{\circ} \mathrm{C}$ for $12 \mathrm{~h}$.

\section{PK-Resistance Assay}

ScN2a cells were seeded on 6-well plates $\left(1 \times 10^{6}\right.$ per well $)$, cultured overnight, and replaced with a medium containing HFIP (0-20 mM) then incubated for 24 h. $500 \mu \mathrm{l}$ of RIPA Buffer (FUJIFILM Wako Pure Chemical Co. Osaka, Japan) per well was added and incubated on ice for $1 \mathrm{~min}$. The solubilized sample was centrifuged at $850 \times g$ at $4{ }^{\circ} \mathrm{C}$ for $10 \mathrm{~min}$, and the solubilized supernatant was collected. Protein concentration in the supernatant was quantified using the Total Protein Quantitation Kit, Bradford Ultra (Novexin Ltd., Cambridge, UK) according to the instruction manual. $100 \mu \mathrm{g}$ of total protein were treated with $10 \mu \mathrm{g} / \mathrm{mL}$ PK at $37^{\circ} \mathrm{C}$ for $30 \mathrm{~min}$. Protease inhibitor cocktail (Nacalai Tesque, INC. Kyoto, Japan) was added to stop the PK activity and incubated at room temperature for $5 \mathrm{~min}$ then centrifuged at $20,000 \times g$ at $4{ }^{\circ} \mathrm{C}$ for $20 \mathrm{~min}$. The sedimented fraction was collected as PK-resistant.

\section{Western Blotting}

Western blotting was performed as previously reported [13]. The membrane was examined with an anti-PrP antibody SAF83 (Bertin Bioreagent. Montigny le Bretonneux, France) diluted with PBS-T (1:1000) for overnight at room temperature as the first antibody then incubated with HRPconjugated anti-mouse IgGs $(\mathrm{H}+\mathrm{L})$ (Promega Co. Madison, WI, USA) as a secondary antibody (1:5000).

\section{Immunofluorescent Microscopy Observation}

The immunofluorescent antibody method was performed as previously reported [8]. Briefly, the fixed cells were incubated overnight at $4^{\circ} \mathrm{C}$ with anti-PrP peptide (PrP 76-90) antibody (1: 200) and $\alpha$-tubulin antibody (1: 500) 
(Sigma-Aldrich. St. Louis, MO, USA). Alexa Fluor® Plus 488-conjugated anti-rabbit IgG (1:200) and Alexa Fluor ${ }^{\circledR}$ 594-conjugated anti-mouse $\operatorname{IgG}(1: 1000)$ were used as a secondary antibody. Fluorescent images were acquired using a microscope IX73 (Olympus Corp., Tokyo, Japan).

\section{JC-1 Staining}

JC-1 (FUJIFILM Wako Pure Chemical Co. Osaka, Japan) was added to the culture medium of $\mathrm{N} 2 \mathrm{a}$ and $\mathrm{ScN} 2 \mathrm{a}$ cells with a final concentration of $5 \mu \mathrm{g} / \mathrm{ml}$ and incubated at $37^{\circ} \mathrm{C}$ for $30 \mathrm{~min}$. After the incubation, cells were washed and replaced with phenol red-free L-15 medium (Thermo Fisher Scientific, Waltham, MA, USA). Fluorescence images were acquired using an microscope IX73 (Olympus Corp., Tokyo, Japan).

\section{Crystal Violet Staining}

The susceptibility of HFIP in cells was evaluated by crystal violet staining. Cells $\left(1 \times 10^{6}\right.$ per well $)$ were seeded onto 6-well plates and cultured overnight; then, the medium was replaced with HFIP-containing medium $(0-50 \mathrm{mM})$. After treatment with HFIP, cells were fixed with $100 \%$ methanol for 30 min then stained with $0.05 \%$ crystal violet (FUJIFILM Wako Pure Chemical Co. Osaka, Japan) for $30 \mathrm{~min}$. Stained cells were visualized using a CKX31 microscope (Olympus Corp., Tokyo, Japan), and the positive area was calculated using ImageJ software (NIH, Bethesda, MD).

\section{Statistical Analysis}

Statistical analysis measured mean and standard deviation (SD) by 3-5 independent studies. The statistical significance of the relation between groups by the F-test and the t-test was shown by the variance ratio test. There was a substantial difference when the risk rate was $p<0.05$.

Acknowledgements We thank Drs. Akiyama and Kawashima for critical discussion. We also thank to Dr. Soga for his technical advice. This work was supported by JSPS Grant No. JP19K2252 (N.H.).

Author Contributions NH supervised the experimental framework and wrote the main manuscript text. TS performed all of experiments and discussion. EM performed cell culture experiments. YI and HY performed CD measurements. KM performed the electron microscopy experiments. MN, TY, TO, and FK, supervised the analyses. All authors discussed the analyses and results.

\section{Declarations}

Conflict of interest The authors declare no competing financial interests.
Open Access This article is licensed under a Creative Commons Attribution 4.0 International License, which permits use, sharing, adaptation, distribution and reproduction in any medium or format, as long as you give appropriate credit to the original author(s) and the source, provide a link to the Creative Commons licence, and indicate if changes were made. The images or other third party material in this article are included in the article's Creative Commons licence, unless indicated otherwise in a credit line to the material. If material is not included in the article's Creative Commons licence and your intended use is not permitted by statutory regulation or exceeds the permitted use, you will need to obtain permission directly from the copyright holder. To view a copy of this licence, visit http://creativecommons.org/licenses/by/4.0/.

\section{References}

1. Prusiner SB (1998) Prions. Proc Natl Acad Sci USA 95:13363-13383

2. Wang H, Rhoads DD, Appleby BS (2019) Human prion diseases. Curr Opin Infect Dis 32:272-276

3. Collins S, McLean CA, Masters CL (2001) Gerstmann-SträusslerScheinker syndrome, fatal familial insomnia, and kuru: a review of these less common human transmissible spongiform encephalopathies. J Clin Neurosci 8:387-397

4. Ghani AC, Donnelly CA, Ferguson NM, Anderson RM (2002) The transmission dynamics of BSE and vCJD. C R Biol 325:37-47

5. López Garcia F, Zahn R, Riek R, Wüthrich K (2000) NMR structure of the bovine prion protein. Proc Natl Acad Sci USA 97:8334-8339

6. Haïk S, Brandel JP (2011) Biochemical and strain properties of CJD prions: complexity versus simplicity. J Neurochem 119:251-261

7. Harris DA (1999) Cell biological studies of the prion protein. Curr Issues Mol Biol 1:65-75

8. Hachiya NS, Watanabe K, Sakasegawa Y, Kaneko K (2004) Microtubules-associated intracellular localization of the NH2terminal cellular prion protein fragment. Biochem Biophys Res Commun 313:818-823

9. Hachiya NS, Watanabe K, Yamada M, Sakasegawa Y, Kaneko K (2004) Anterograde and retrograde intracellular trafficking of fluorescent cellular prion protein. Biochem Biophys Res Commun 315:802-807

10. Hachiya NS, Yamada M, Watanabe K, Jozuka A, Ohkubo T, Sano K, Takeuchi Y, Kozuka Y, Sakasegawa Y, Kaneko K (2005) Mitochondrial localization of cellular prion protein (PrPC) invokes neuronal apoptosis in aged transgenic mice overexpressing PrPC. Neurosci Lett 374:98-103

11. Hachiya NS, Watanabe K, Kawabata MY, Jozuka A, Kozuka Y, Sakasegawa Y, Kaneko K (2005) Prion protein with Y145STOP mutation induces mitochondria-mediated apoptosis and PrPcontaining deposits in vitro. Biochem Biophys Res Commun 327:894-899

12. Faris R, Moore RA, Ward A, Race B, Dorward DW, Hollister JR, Fischer ER, Priola SA (2017) Cellular prion protein is present in mitochondria of healthy mice. Sci Rep 7:41556

13. Shimizu T, Kozuka Y, Kusano M, Nagane M, Yamashita T, Hachiya N (2020) PrP (122-139) is a covert mitochondrial targeting signal of prion protein and it specifically triggers the perinuclear clustering of mitochondria in neuronal culture cells. Biochem Biophys Res Commun 524:301-307

14. Wulf MA, Senatore A, Aguzzi A (2017) The biological function of the cellular prion protein: an update. BMC Biol 15:34

15. Linden $R$ (2017) The biological function of the prion protein: a cell surface scaffold of signaling modules. Front Mol Neurosci 10:77 
16. Edgington TL, Muco E, Maani CV (2021) Sevoflurane. StatPearls Publishing LLC., Treasure Island

17. Palanca BJA, Avidan MS, Mashour GA (2017) Human neural correlates of sevoflurane-induced unconsciousness. Br J Anaesth 119:573-582

18. Kharasch ED, Armstrong AS, Gunn K, Artru A, Cox K, Karol MD (1995) Clinical sevoflurane metabolism and disposition. II. The role of cytochrome P450 2E1 in fluoride and hexafluoroisopropanol formation. Anesthesiology 82:1379-1388

19. Kharasch ED, Karol MD, Lanni C, Sawchuk R (1995) Clinical sevoflurane metabolism and disposition. I. Sevoflurane and metabolite pharmacokinetics. J Am Soc Anesthesiology 82:1369-1378

20. Urner M, Schläpfer M, Herrmann IK, Hasler M, Schimmer RR, Booy C, Roth Z'graggen B, Rehrauer H, Aigner F, Minshall RD, Stark WJ, Beck-Schimmer B (2015) Insight into the beneficial immunomodulatory mechanism of the sevoflurane metabolite hexafluoro-2-propanol in a rat model of endotoxaemia. Clin Exp Immunol 181:468-479

21. Hirota N, Mizuno K, Goto Y (1997) Cooperative alpha-helix formation of beta-lactoglobulin and melittin induced by hexafluoroisopropanol. Protein Sci 6:416-421

22. Juszczyk P, Kołodziejczyk AS, Grzonka Z (2005) Circular dichroism and aggregation studies of amyloid beta (11-8) fragment and its variants. Acta Biochim Pol 52:425-431

23. Pachahara SK, Nagaraj R (2015) Probing the role of aromatic residues in the self-assembly of A $\beta(16-22)$ in fluorinated alcohols and their aqueous mixtures. Biochem Biophys Rep 2:1-13

24. Pachahara SK, Adicherla H, Nagaraj R (2015) Self-assembly of $A \beta 40, A \beta 42$ and $A \beta 43$ peptides in aqueous mixtures of fluorinated alcohols. PLoS ONE 10:e0136567

25. Krance SH, Luke R, Shenouda M, Israwi AR, Colpitts SJ, Darwish L, Strauss M, Watts JC (2020) Cellular models for discovering prion disease therapeutics: progress and challenges. J Neurochem 153:150-172

26. Kocisko DA, Caughey B (2006) Searching for anti-prion compounds: cell-based high-throughput in vitro assays and animal testing strategies. Methods Enzymol 412:223-234

27. Karamyshev AL, Tikhonova EB, Karamysheva ZN (2020) Translational control of secretory proteins in health and disease. Int $\mathbf{J}$ Mol Sci 21:2538

28. Frontzek K, Aguzzi A (2020) Recent developments in antibody therapeutics against prion disease. Emerg Top Life Sci 4:169-173

29. Furuya K, Kawahara N, Yamakawa Y, Kishida H, Hachiya NS, Nishijima M, Kirino T, Kaneko K (2006) Intracerebroventricular delivery of dominant negative prion protein in a mouse model of iatrogenic Creutzfeldt-Jakob disease after dura graft transplantation. Neurosci Lett 402:222-226

30. Kishida H, Sakasegawa Y, Watanabe K, Yamakawa Y, Nishijima M, Kuroiwa Y, Hachiya NS, Kaneko K (2004) Non-glycosylphosphatidylinositol (GPI)-anchored recombinant prion protein with dominant-negative mutation inhibits PrPSc replication in vitro. Amyloid 11:14-20

31. Giles K, Olson SH, Prusiner SB (2017) Developing therapeutics for PrP prion diseases. Cold Spring Harb Perspect Med 7:a023747

32. Wille H, Zhang G-F, Baldwin MA, Cohen FE, Prusiner SB (1996) Separation of scrapie prion infectivity from PrP amyloid polymers. J Mol Biol 259:608-621

33. Nichols MR, Moss MA, Reed DK, Cratic-McDaniel S, Hoh JH, Rosenberry TL (2005) Amyloid-beta protofibrils differ from amyloid-beta aggregates induced in dilute hexafluoroisopropanol in stability and morphology. J Biol Chem 280:2471-2480

34. Shigemitsu Y, Iwaya N, Goda N, Matsuzaki M, Tenno T, Narita A, Hoshi M, Hiroaki H (2016) Nuclear magnetic resonance evidence for the dimer formation of beta amyloid peptide 1-42 in 1,1,1,3,3,3-hexafluoro-2-propanol. Anal Biochem 498:59-67
35. Naito A, Kawamura I (2007) Solid-state NMR as a method to reveal structure and membrane-interaction of amyloidogenic proteins and peptides. Biochim Biophys Acta 1768:1900-1912

36. Popova LA, Kodali R, Wetzel R, Lednev IK (2010) Structural variations in the cross-beta core of amyloid beta fibrils revealed by deep UV resonance Raman spectroscopy. J Am Chem Soc 132:6324-6328

37. Barducci A, Chelli R, Procacci P, Schettino V, Gervasio FL, Parrinello $\mathrm{M}$ (2006) Metadynamics simulation of prion protein: betastructure stability and the early stages of misfolding. J Am Chem Soc 128:2705-2710

38. Terry C, Wadsworth JDF (2019) Recent advances in understanding mammalian prion structure: a mini review. Front Mol Neurosci 12:169-169

39. Wang L-Q, Zhao K, Yuan H-Y, Wang Q, Guan Z, Tao J, Li X-N, Sun Y, Yi C-W, Chen J, Li D, Zhang D, Yin P, Liu C, Liang Y (2020) Cryo-EM structure of an amyloid fibril formed by fulllength human prion protein. Nat Struct Mol Biol 27:598-602

40. Sarnataro D, Pepe A, Zurzolo C (2017) Cell biology of prion protein. Prog Mol Biol Transl Sci 150:57-82

41. Miesbauer M, Rambold AS, Winklhofer KF, Tatzelt J (2010) Targeting of the prion protein to the cytosol: mechanisms and consequences. Curr Issues Mol Biol 12:109-118

42. Barret A, Tagliavini F, Forloni G, Bate C, Salmona M, Colombo L, De Luigi A, Limido L, Suardi S, Rossi G, Auvré F, Adjou KT, Salès N, Williams A, Lasmézas C, Deslys JP (2003) Evaluation of quinacrine treatment for prion diseases. J Virol 77:8462-8469

43. Kamatari YO, Hayano Y, Yamaguchi K, Hosokawa-Muto J, Kuwata K (2013) Characterizing antiprion compounds based on their binding properties to prion proteins: implications as medical chaperones. Protein Sci 22:22-34

44. Yamasaki T, Suzuki A, Hasebe R, Horiuchi M (2014) Comparison of the anti-prion mechanism of four different anti-prion compounds, anti-PrP monoclonal antibody 44B1, pentosan polysulfate, chlorpromazine, and U18666A, in prion-infected mouse neuroblastoma cells. PLoS ONE 9:e106516

45. Grassi S, Giussani P, Mauri L, Prioni S, Sonnino S, Prinetti A (2020) Lipid rafts and neurodegeneration: structural and functional roles in physiologic aging and neurodegenerative diseases. J Lipid Res 61:636-654

46. Simons K, Toomre D (2000) Lipid rafts and signal transduction. Nat Rev Mol Cell Biol 1:31-39

47. Shaikh SR, Edidin MA (2006) Membranes are not just rafts. Chem Phys Lipids 144:1-3

48. Bach C, Gilch S, Rost R, Greenwood AD, Horsch M, Hajj GN, Brodesser S, Facius A, Schädler S, Sandhoff K, Beckers J, LeibMösch C, Schätzl HM, Vorberg I (2009) Prion-induced activation of cholesterogenic gene expression by Srebp2 in neuronal cells. J Biol Chem 284:31260-31269

49. Gilch S, Kehler C, Schätzl HM (2006) The prion protein requires cholesterol for cell surface localization. Mol Cell Neurosci 31:346-353

50. Marshall KE, Hughson A, Vascellari S, Priola SA, Sakudo A, Onodera T, Baron GS (2017) PrP knockout cells expressing transmembrane PrP resist prion infection. J Virol 91:e01686-16

51. Taraboulos A, Scott M, Semenov A, Avrahami D, Laszlo L, Prusiner SB (1995) Cholesterol depletion and modification of $\mathrm{COOH}$-terminal targeting sequence of the prion protein inhibit formation of the scrapie isoform. J Cell Biol 129:121-132

52. Prior M, Lehmann S, Sy MS, Molloy B, McMahon HE (2007) Cyclodextrins inhibit replication of scrapie prion protein in cell culture. J Virol 81:11195-11207

53. Zhang M, Peyear T, Patmanidis I, Greathouse DV, Marrink SJ, Andersen OS, Ingólfsson HI (2018) Fluorinated alcohols' effects on lipid bilayer properties. Biophys J 115:679-689 
54. Ennaceur SM, Sanderson JM (2005) Micellar aggregates formed following the addition of hexafluoroisopropanol to phospholipid membranes. Langmuir 21:552-561

55. Lioudyno MI, Broccio M, Sokolov Y, Rasool S, Wu J, Alkire MT, Liu V, Kozak JA, Dennison PR, Glabe CG, Lösche M, Hall JE (2012) Effect of synthetic a $\beta$ peptide oligomers and fluorinated solvents on Kv1.3 channel properties and membrane conductance. PLoS ONE 7:e35090
56. Pardridge WM (1998) CNS drug design based on principles of blood-brain barrier transport. J Neurochem 70:1781-1792

Publisher's Note Springer Nature remains neutral with regard to jurisdictional claims in published maps and institutional affiliations. 